\title{
Influence of storage conditions on germination of winter wheat seeds (Triticum aestivum L.) in relation to agriculture systems
}

\author{
Vasyl Petrenko \\ Institute of Food Resources, \\ Maria Raskova St. 4a, \\ Kiev, 02660, Ukraine \\ E-mail:whippet85@mail.ru
}

In this study we evaluated different terms and modes of winter wheat seeds storage. The study was aimed to determine the effect of three modes and six terms on the laboratory germination as well as to ascertain the optimal regime of storage. Wheat was grown on leached black soil under three different fertilization conditions in the northern part of Ukraine. Field and laboratory experiments were conducted in the Agronomy Experimental Station of the National University of Life and Environmental Sciences of Ukraine. The data were analyzed using the ANOVA method.

Sowing properties depended more on weather conditions after harvesting and on terms of storage in a long-term storage period. Agriculture systems (fertilizing and plant protection systems) define sowing properties not more than $16 \%$. The optimal storage period for winter seeds under different conditions was 6-18 months. In need of further storage, it is necessary to use the Cool mode.

Key words: agriculture system, laboratory germination, terms and modes of storage, wheat seeds

\section{INTRODUCTION}

High grain yield and quality are important for food and feed production. Wheat (Triticum aestivum L.) is the staple food for more than 35 percent of world population (Jing, Chang, 2003; Gomez et al., 2009). The winter wheat is the most common cereal crop in Ukraine and it has a big export meaning for the economy. The annual production of wheat grain is currently estimated in 16-22 million tons. And more than 1.5 million tons of the harvest are used as seeds for the sowing. So the problem of wheat seeds storage is important for Ukraine. And also seed characteristics are usually an essential process in seedling establishment and plant development to obtain seedling numbers resulting in higher seed crop (Almansouri et al., 2001; Adamenko, 2012).

Every modern agriculture system includes such components as: scientifically well-founded organisation of the ground terrain of economy; rational frame of crop rotation; system of soil process- ing; fertilizing, plant protection system, system of seed-growing and meliorative receptions directed on protection against erosion (Petrenko et al., 2013). High yields of today's modern wheat cultivars require high input which leads to both higher production costs and greater risk of environmental pollution. Increasing public awareness of the latter, along with growing consumer demand for healthier products, has led, on the one hand, to greater criticism being levelled at this type production model and, on the other hand, to heightened emphasis on crops grown under integrated-management and organic systems (Cupic et al., 2005; Dinelli et al., 2013). This also applies to wheat (Guarda et al., 2008; Janušauskaite, 2013). In Ukraine, like in many other countries, agriculture inspection is oriented towards organic farming, whose prime objective is to solve environmental and food safety problems. But low-input management for wheat production (less fungicide and nitrogen fertilisers) could affect seed germination. The impact of the previous crop could also be a determining factor for wheat 
quality. Organic producers give their preference to competitive wheat cultivars, with high disease resistance and high competitive power against weeds (Jablonskyte-Rasce et al., 2013).

Seed germination could lead to the vegetative plant growth initiation. Seed germination is the first critical stage in any plant life cycle and determines the optimal plant density, crop uniformity and management options. Certain quantities of seeds remain unsold every year and are kept at various storage conditions. Environmental temperature, relative humidity, gas composition of air and pathogenic microorganisms are the most important factors influencing seed viability and longevity during the storage period. Interdependence of these four factors during seed storage and their subsequent effect on germination have been recognized for different regions (Al-Yaha, 2001; Strelec et al., 2010)

Researchers defined germination as the appearance of the first signs of growth. Successful crop production requires the use of high quality seeds to achieve better stand establishment and higher crop yield. This high level of seed quality is demanded by the end user to assure maximum seedling emergence and stand establishment in the field (Tekrony, 2006). This critically evaluated studies on the viability of cereal seeds and allowed to obtain a simple mathematical relation between temperature, moisture content and viability. The relationship was apparently similar for wheat, barley, and oats.

Authors (Collins, 2010; Grover, 2013) stated that a significant part of wheat cultivar had a long period of seeds postharvest maturing. On the one hand, this phenomenon is considered an important economic sign as, preserving seeds from intergrowth at the first stages of maturity, it promotes augmentation of the term of their storage, and, on the other hand, it is an essential lack as long span seeds are not applicable for sowing. That is why it is necessary to define optimal storage terms and modes of seeds with different initial quality.

Different periods and agreements of wheat seeds storage were studied, but there is no common opinion on the question of the best conditions to the long-term period of storage for different pristine quality of seeds (Villers et al., 2010; Lobanov, 1978; Polonskiy, 2003).

\section{MATERIALS AND METHODS}

A field experiment was set up at the National University of Life and Environmental Sciences of the Ukraine Agronomy Experimental Station during the period 2009-2013. The field experiment plan provided a combination of 3 different agriculture systems in the typical for the Woodland zone crop rotation. The soil of the experimental site is clay loam (Luvic Chernozems, Cl) with a humus content of 4.3-4.6\%, $\mathrm{pH}_{\mathrm{KCl}} 6.8-7.0$, $\mathrm{P}_{2} \mathrm{O}_{5}$ 176-187 $\mathrm{mg} \mathrm{kg}^{-1}, \mathrm{~K}_{2} \mathrm{O} 440-451 \mathrm{mg} \mathrm{kg}^{-1}$.

In our researches we used the samples of the winter wheat (the cultivar "Natsionalna" of the Ukrainian breading) grown by the biological, ecological and intensive systems of agriculture. The wheat pre-crop was clover in all experimental years. The fertilizing and plant protection systems differed essentially concerning agriculture systems. The control treatment was the intensive system model which provided applying for the winter wheat $\mathrm{N}_{130}$, $\mathrm{K}_{114}, \mathrm{P}_{126} \mathrm{~kg} \mathrm{ha}^{-1}$ and also intensive usage of the recommended pesticides by the program of ensuring the productivity of arable lands (herbicide Grodyl 75 WG and fungicide Racsile).

The models of the biological and ecological agriculture were compared with the control treatment. These agriculture systems have a strong difference most in fertilizing and plant protection submitted below (Tanchik, 2009). In the first system organic fertilizers $\left(24 \mathrm{t} \mathrm{ha}^{-1}\right)$ were applied in crop rotation, without any mineral fertilizers and pesticides. In a break-down, about $17 \mathrm{t} \mathrm{ha}^{-1}$ of this fertilizing was dunged and there were no less than $7 \mathrm{t} \mathrm{ha}^{-1}$ stubbly remains (like clover or corn eddish). In particular, by the wheat cultivation there was only seed processing by a biological fertilizer before sowing (Azofit). Exclusively, mechanical and biological means were used against pests, diseases and weeds. This field experiment was carried out in a certified organic field in the Agronomy Experimental Station.

The ecological system envisaged the usage of organic and mineral fertilizers in particular for wheat $\mathrm{N}_{100}, \mathrm{~K}_{34}, \mathrm{P}_{64} \mathrm{~kg} \mathrm{ha}^{-1}$ and norms of pesticides grounded according to the criterion of the ecological economic threshold of harmful organisms.

Weather conditions in experimental years were based on the data from the meteorological site of the National University of Life and Environmental Sciences of the Ukraine Agronomy Experimental 
Station. Figure 1 shows the rainfall and mean air temperature over the 3-year study. From middle of March till 20th of May in 2010 there was not any rain and in combination with high temperatures it caused low quality of harvested grain. The spring in 2011 was really dry too, but in June the quantity of rainfall covered the shortage. The differences in temperature between the experimental years were relatively modest. All of them were mostly similar to the average long-term mean.

After harvesting seeds were refined and dried up to the moisture content $13.5-14.0 \%$. The dry seed is characterized by a low state of metabolism capable of withstanding extreme variations in its environment. Then the seeds were stored for two years in three different modes (temperature and packing conditions) that are the most popular in an agriculture enterprise: the first mode - in a non-heated barn in burlap bags (in a dry state); the second one - also in a non-heated barn but in hermetic plastic bags, white colour outside and black inside, thick 90 micron (without air access), and the third mode - in a cold storage room, with the temperature $+6 \pm 2{ }^{\circ} \mathrm{C}$ in burlap bags (in a cool state). The mass of each sample of seeds was $50 \mathrm{~kg}$.

The laboratory germination test was done before putting seeds on storage and then after three,

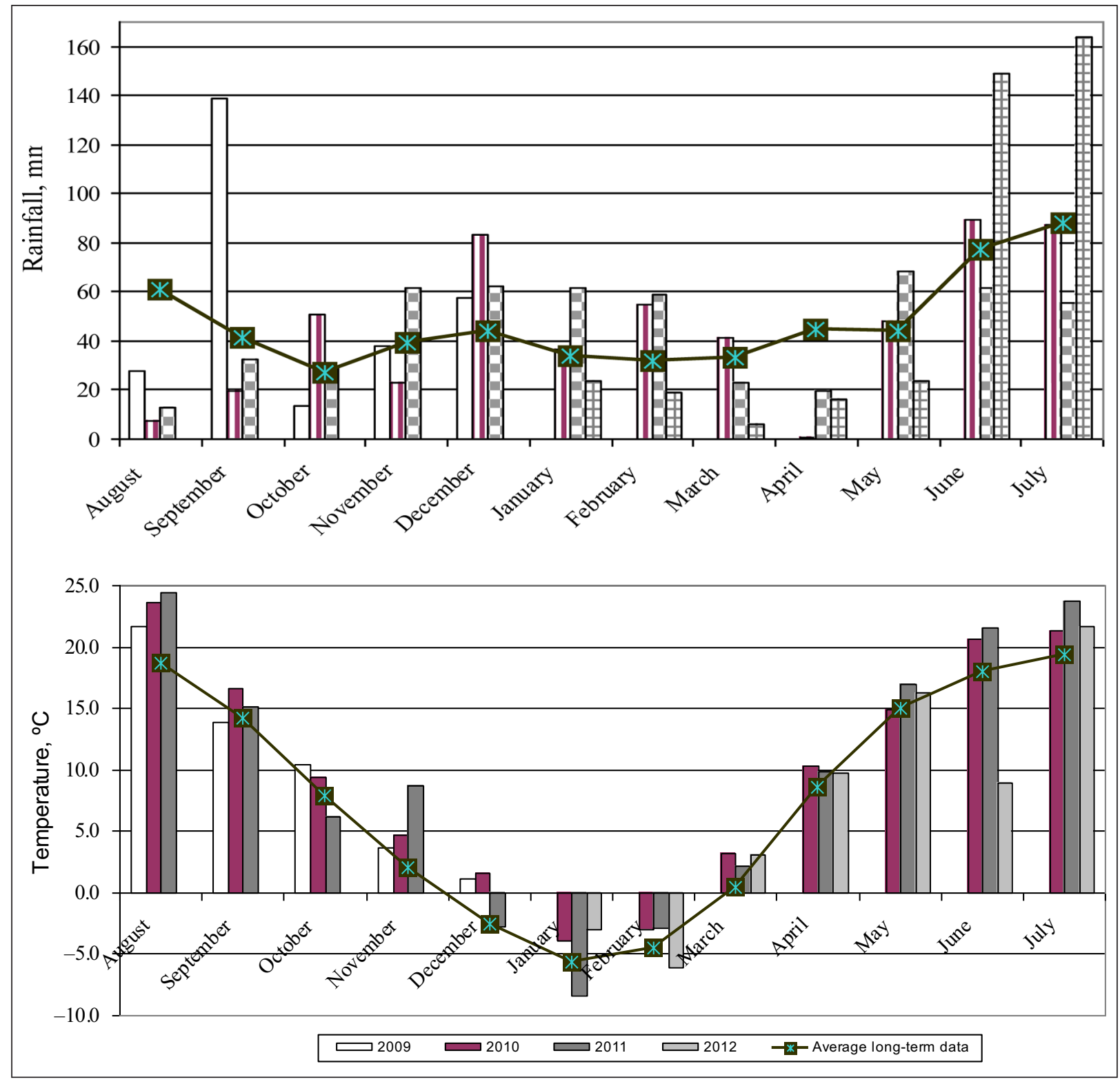

Fig. 1. Meteorological conditions of experimental years 
six, twelve, eighteen and twenty four months. One hundred seeds were placed in Petri dishes on two layers of filter paper moistened with $10 \mathrm{ml}$ of distilled water, and were incubated at $20 \pm 1{ }^{\circ} \mathrm{C}$ in the thermostat. Prior to the germination test, the stored seeds were surface sterilized with $96 \%$ ethyl alcohol. For each treatment, five replicates of 100 seeds were used. Seeds were considered to be germinated with the emergence of the chit. The number of germinated seeds was counted at 4 and 8 days after planting (Fig. 2). The final percentage of germinated seeds was calculated for 8 days following seed sowing. The results are presented as means of the germination percentages.

The experiments consisted of a randomized complete block design which included 54 treat-

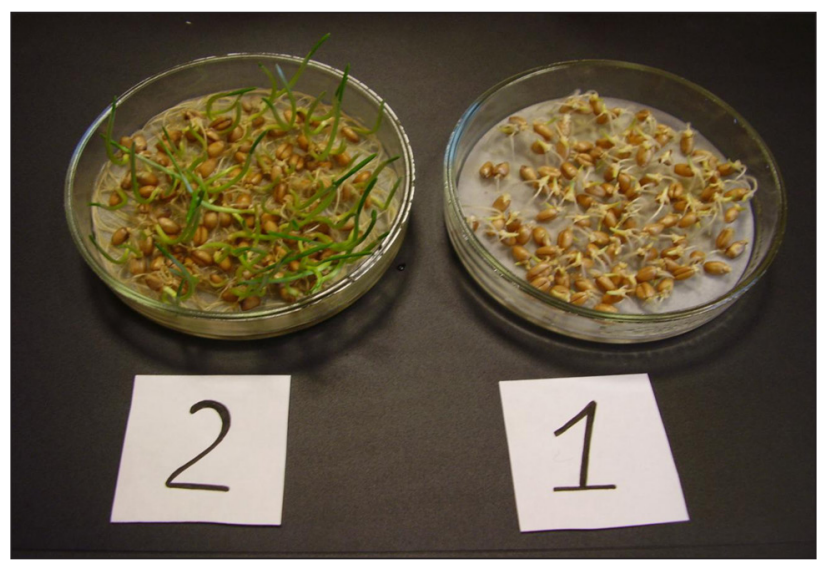

Fig. 2. Laboratory germination of winter wheat seeds: 2 - eight, 1 - four days after sowing

ment combinations consisting of three agriculture systems, three modes of storage and six terms. The data of laboratory germination tests were processed by a two-factor $\mathrm{N}$ regime and year analysis of variance (ANOVA) to establish the treatment effects. Treatment means were compared using the Fisher's protected least significant difference (LSD) test at $P \leq 0.05$. Contrasts were used to determine the effect of storage terms, modes, weather conditions and agriculture systems. The Fisher's LSD $(\mathrm{P} \leq 0.05)$ test was used to estimate significant treatment effects.

\section{RESULTS AND DISCUSSION}

According to the data of three-year tests, the effect of agriculture systems on the sowing prop- erties of winter wheat seeds differed between years (Figs. 3, 4). Detailed numerical data were adducted lower in Tables 1 and 2. We have the defined average value of seed germination before storage by all variants of experience. It has compounded $65 \pm 1.83 \%$ (basic level). The lowest seeds germinating capacity has been fixed in 2009 , in consequence more quantity of droughty days throughout the vegetation season. Scientific

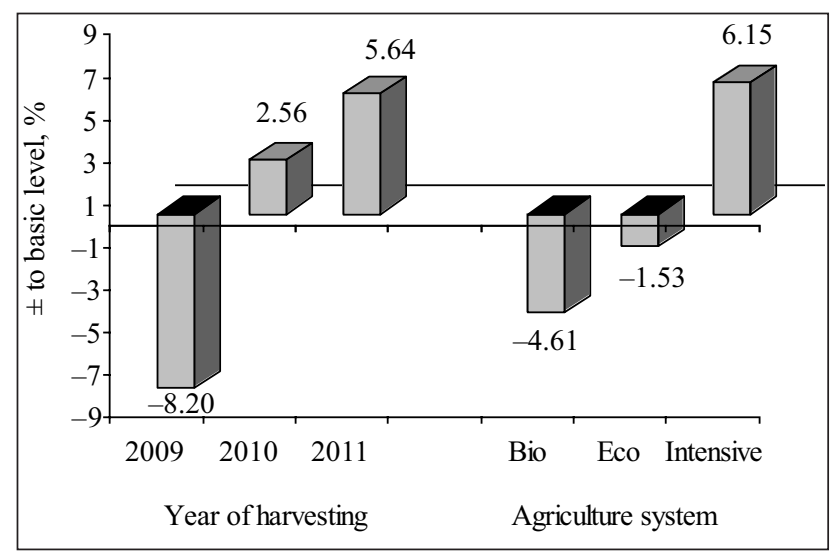

Fig. 3. Influence of weather conditions in harvesting years and agriculture systems on laboratory germination of winter wheat seeds before storage

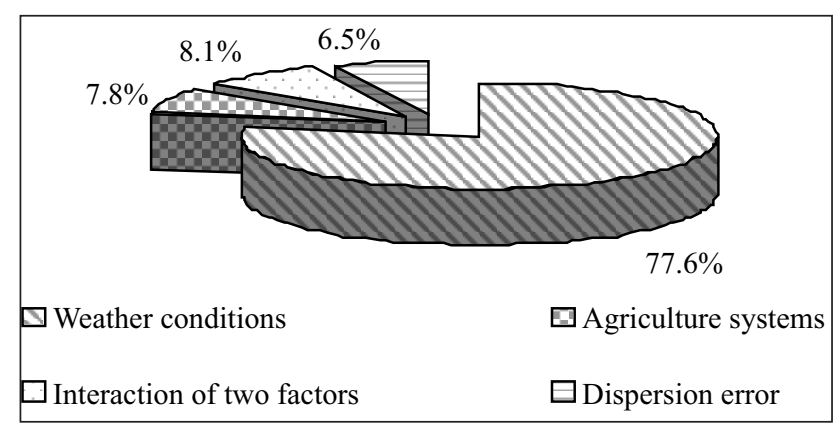

Fig. 4. The factor diagram of the influence of weather conditions in the experimental years and agriculture systems on wheat seeds germination before storage

literature indicates that not only inorganic nutrition but more weather conditions, moisture and heat regime, during grain filling and maturation stages, have high significance on the grain sowing properties (Guarda et al., 2008; Stahl, Steiner, 1998). This could lead to differences in the process of grain postharvest after-ripening in different research years. Concerning agriculture 
Table 1. Laboratory germination of winter wheat seeds (\%) due to the year of harvest at long-term storage

\begin{tabular}{c|c|c|c|c|c|c}
\hline \multirow{2}{*}{$\begin{array}{c}\text { Harvesting } \\
\text { year }\end{array}$} & \multirow{2}{*}{ Before storage } & \multicolumn{5}{|c}{ Term of storage, month } \\
\cline { 3 - 7 } & & $\mathbf{3}$ & $\mathbf{6}$ & $\mathbf{1 2}$ & $\mathbf{1 8}$ & $\mathbf{2 4}$ \\
\hline 2009 & $59.67 \pm 1.45$ & $68.33 \pm 2.35$ & $91.00 \pm 1.04$ & $96.78 \pm 0.61$ & $91.56 \pm 0.97$ & $85.22 \pm 1.72$ \\
\hline 2010 & $66.33 \pm 1.42$ & $85.67 \pm 2.25$ & $94.22 \pm 1.07$ & $98.91 \pm 0.64$ & $92.44 \pm 1.02$ & $87.67 \pm 1.74$ \\
\hline 2011 & $68.67 \pm 1.64$ & $78.33 \pm 1.94$ & $94.56 \pm 0.80$ & $95.60 \pm 0.44$ & $91.67 \pm 0.91$ & $86.56 \pm 1.46$ \\
\hline
\end{tabular}

The standard deviation of the mean $(\mathrm{p}=0.05)$ is presented.

systems, germination only at an intensive system of agriculture was above the basic level. Ecological and biological systems provided essentially the worst values of the index.

The dispersion analysis, that we made using the results of researches, specifies a high level influence of weather conditions in the experimental years on seed germination right after harvesting. Taking into account their interaction with agriculture systems, this factor defined the index $85 \%$. So from this it follows that the weather factor is more important than agriculture systems.

The data of wheat seed germination in dependence on three cultivation seasons and different periods of storage are presented in Table 1.

Before storage the germination test was made in two weeks after harvesting in each year of the experiment. The highest initial data on the investigated index were received in 2011. It can be explained by better weather conditions in comparison with previous years for post harvesting after-ripening. The investigated index was the lowest before putting seeds on storage that is co-ordinated with the data (Collins, 2010) about the long period of postharvest maturing. As for terms of storage, seed germination grew up on the average from 27 to $37 \%$ compared with the initial data to the highest in 12-month storage. After that, seeds gradually started to reduce laboratory germination, but by the end of the storage period it was $26-44 \%$ above pristine indexes.
So the weather conditions of the experimental year have a significant influence on seed sowing properties $\left(\mathrm{LSD}_{05}=4.1\right)$ in all the period of storage.

As to influence of agriculture systems on seed germination in long-term storage, it is necessary to pay attention to variability of the index depending on them (Table 2). Seeds were grown under biological system raised germination for one year period of storage more than $34 \%$. Less increase was for two other systems - 26-30\% per first 12 months. It was promoted by storage of seeds at humidity below the critical value. The difference between the terms of storage was significant $\left(\mathrm{LSD}_{05}=3.9\right)$.

Fertilizing and plants protection systems had no significant effect on the long-term period of storage, to the extent of 18 and 24 months. But before the beginning of the experiment the difference between agriculture systems was significant $\left(\mathrm{LSD}_{05}=2.9\right)$. Literature evidence suggested that laboratory germination of winter wheat must be no less than $92 \%$, for reception of the optimal thickness of sowings (Abedi et al., 2010; Lobanov, 2008). So in our experiment we have the highest indexes from 6 to 18 months of storage.

Table 3 apaprently shows that throughout the first six months of storage germination increased more intensively at the Dry mode and at storage in the Cool mode it was the most sluggish. We traced these tendencies for 12 months, then germinating capacity has started to drop. The data which we have received are co-ordinated with conclusions

Table 2. Laboratory germination of winter wheat seeds (\%) due to agriculture system at long-term storage

\begin{tabular}{c|c|c|c|c|c|c}
\hline \multirow{2}{*}{$\begin{array}{c}\text { Agriculture } \\
\text { system }\end{array}$} & \multirow{2}{*}{ Before storage } & \multicolumn{5}{|c}{ Term of storage, month } \\
\cline { 3 - 7 } & & $\mathbf{3}$ & $\mathbf{6}$ & $\mathbf{1 2}$ & $\mathbf{1 8}$ & $\mathbf{2 4}$ \\
\hline Biological & $62.00 \pm 1.44$ & $77.22 \pm 3.63$ & $91.08 \pm 2.47$ & $96.33 \pm 0.55$ & $91.00 \pm 1.03$ & $86.56 \pm 1.56$ \\
\hline Ecological & $64.00 \pm 1.27$ & $76.00 \pm 3.72$ & $94.78 \pm 2.49$ & $94.22 \pm 0.77$ & $92.33 \pm 1.08$ & $86.22 \pm 1.43$ \\
\hline Intensive & $69.67 \pm 1.01$ & $79.33 \pm 3.52$ & $93.11 \pm 2.52$ & $95.67 \pm 0.87$ & $92.33 \pm 0.93$ & $86.67 \pm 1.54$ \\
\hline
\end{tabular}

The standard deviation of the mean $(p=0.05)$ is presented. 
Table 3. Laboratory germination of winter wheat seeds (\%) due to the mode of storage at long-term storage

\begin{tabular}{c|c|c|c|c|c|c}
\hline \multirow{2}{*}{ Storage mode } & \multirow{3}{*}{$\begin{array}{c}\text { Before } \\
\text { storage }\end{array}$} & \multicolumn{5}{|c}{ Term of storage, month } \\
\cline { 3 - 8 } & \multirow{3}{*}{6} & $\mathbf{3}$ & $\mathbf{6}$ & $\mathbf{1 2}$ & $\mathbf{1 8}$ & $\mathbf{2 4}$ \\
\hline Dry mode & $84.67 \pm 2.67$ & $94.56 \pm 0.47$ & $94.89 \pm 0.73$ & $93.89 \pm 0.61$ & $87.00 \pm 0.87$ \\
\cline { 4 - 8 } & \multirow{2}{*}{$65.00 \pm 1.91$} & $76.00 \pm 2.79$ & $96.11 \pm 0.45$ & $95.44 \pm 0.69$ & $89.22 \pm 0.72$ & $81.44 \pm 0.47$ \\
\cline { 3 - 8 } & & $71.67 \pm 2.72$ & $89.11 \pm 2.37$ & $95.89 \pm 0.48$ & $92.56 \pm 0.69$ & $91.00 \pm 1.18$ \\
\hline
\end{tabular}

The standard deviation of the mean $(\mathrm{p}=0.05)$ is presented.

(Dromantiene et al., 2013; Strelec et al., 2010; Villers et al., 2010) about enriching of wheat grain sowing properties at short-term storage.

For the 24-month storage period laboratory germination was at high level, exclusively in samples that were stored in the Cool mode. We marked gradual reduction of the index in the second half of the storage period. Most intensively this process descended at seeds storage in the mode "Without Air Access".

The graph presented below showed the importance of factors which influenced sowing properties of grain at its long-term storage (Fig. 5). We can approve that storage terms have the greatest influence on dynamics of laboratory germination. At conducting the two-factor analysis of influence of the storage modes (Factor A) and terms (Factor $\mathrm{B}$ ) on germination, we defined the major influence of the factor B $-63-74 \%$. So, we compared this factor with growing factors (weather conditions and agriculture systems). Both of them had less value than the terms of storage. That particular data was coordinated with the results of other authors (Li et al., 2008). That is why we can confirm that in the process of long-term wheat seeds storage the term of storage has the greatest value from the four studied factors.

\section{CONCLUSIONS}

1. Weather conditions of harvesting years were the most important factor that has influence on germination before storage of seeds. They were more optimal in 2011. Agriculture systems define sowing properties not more than by $16 \%$.

2 . For the two-year storage period, dynamic of winter wheat seeds germination was more dependent on the terms of storage as compared with

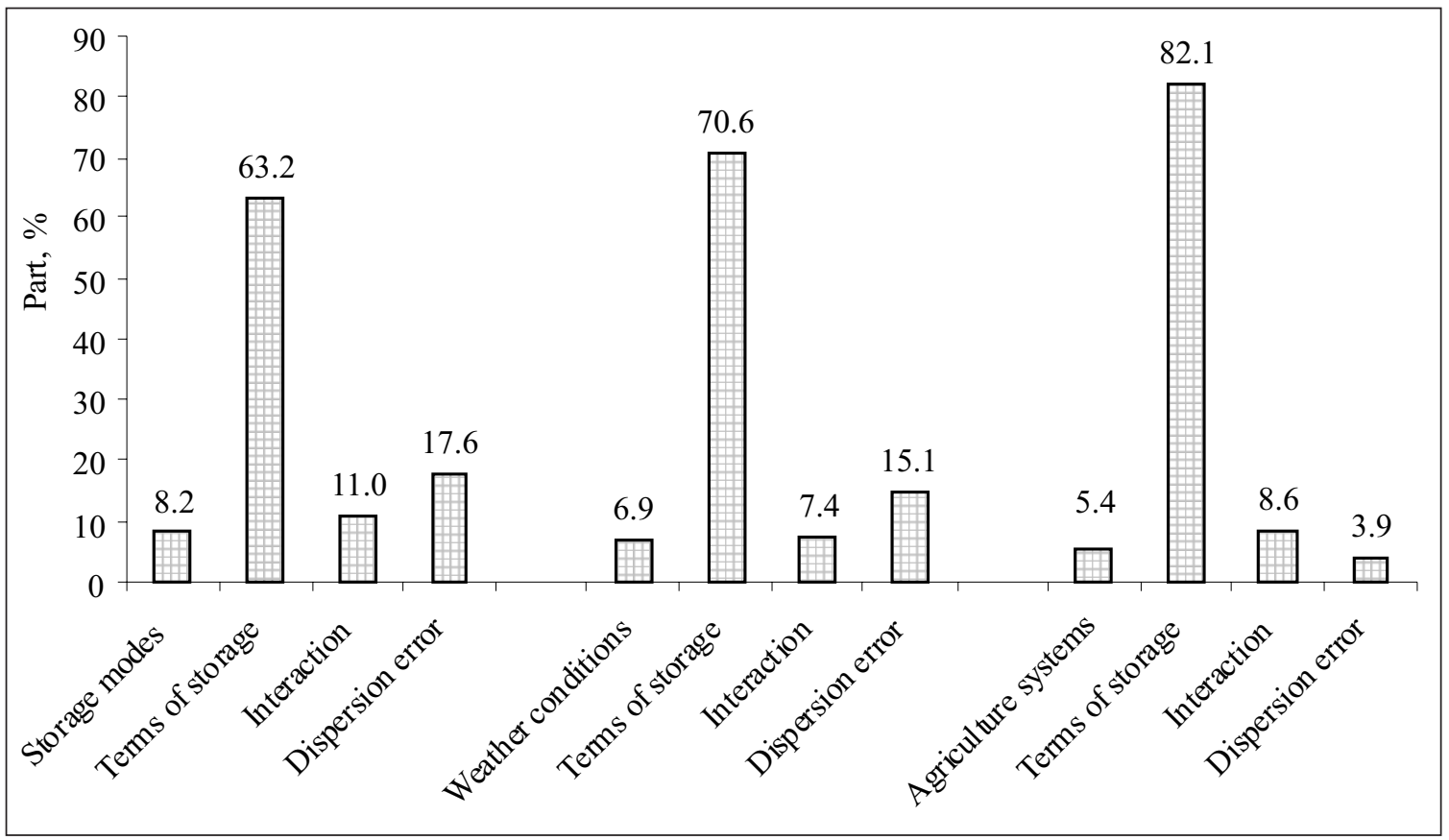

Fig. 5. Influence of storage modes, weather conditions and agriculture systems on laboratory germination depending on the terms of storage 
other studied factors. This value was from $63 \%$ to $82 \%$.

3. The optimal storage period for winter seeds under different conditions was 6-18 months. In need of further storage, it is necessary to use the Cool mode.

\section{ACKNOWLEDGEMENTS}

This work was done collaterally with the Department of Agriculture and Herbology of the National University of Life and Environmental Sciences of Ukraine.

Received 11 March 2014 Accepted 26 June 2014

\section{REFERENCES}

1. Abedi T., Alemzadeh A., Kazemeini S. 2010. Effect of organic and inorganic fertilizers on grain yield and protein banding pattern of wheat. Australian Journal of Crop Science. Vol. 6(4). P. 384-389.

2. Almansouri A., Abid H., Ali J. 2001. Suitability of different wheat varieties grown in NWFP for bread making and effect of storage time on its quality. Pakistan Journal of Nutrition. Vol. 8. P. 616-619.

3. Al-Yahya S. A. 2001. Effect of storage conditions on germination in wheat. Journal of Agronomy and Crop Science. Vol. 186. P. 273-279.

4. Collins P. J. 2010. Research on stored product protection in Australia: a review of past, present and future directions. Julius-Kuhn-Archiv. Vol. 425. P. 3-13. Available from: http://dx.doi.org/10.5073/ jka.2010.425.101

5. Cupic T., Popovic S., Grljusic S., Tucak M., Andric L., Simic B. 2005. Effect of storage time on alfalfa seed quality. Journal of Central European Agriculture. Vol. 6(1). P. 65-68.

6. Dinelli G., Marotti I., Silvestro R., Bosi S., Bregola V., Accorsi M., Loretto A., Benedettelli S., Ghiselli L., Catizone P. 2013. Agronomic, nutritional and nutraceutical aspects of durum wheat cultivars under low input agricultural management. Italian Journal of Agronomy. Vol. 8(2). P. 8593. Available from: http://dx.doi.org/10.4081/ ija.2013.e12

7. Dromantienė R., Pranckietienè I., Sidlauskas G., Pranckietis V. 2013. Changes in technological properties of common wheat (Triticum aestivum L.) grain as influenced by amino acid fertilizer. Zemdirbyste-Agriculture. Vol. 100(1). P. 57-62. Available from: http://dx.doi.org/ 10.13080/z-a.2013.100.008

8. Guarda G., Padovana S., Delogu G. 2008. Grain yield, nitrogen-use efficiency and baking quality of old and modern Italian bread-wheat cultivars grown at different nitrogen levels. European Journal of Agronomy. Vol. 21(2). P. 181-192.

9. Gomez M., Aparicio N., Ruiz-Pariz E., Oliete B., Cabarello P. 2009. Evolution of bread-making quality of Spanish bread-wheat genotypes. Spanish Journal of Agricultural Research. Vol. 7(3). P. 585-595.

10. Grover D. K. 2013. Farm level estimates of wheat grain losses in Amristar district of Punjab. Agricultural Science Digest. Vol. 33(1). P. 1-8.

11. Guarda G., Padovana S., Delogu G. 2008. Grain yield, nitrogen-use efficiency and baking quality of old and modern Italian bread-wheat cultivars grown at different nitrogen levels. European Journal of Agronomy. Vol. 21(2). P. 181-192.

12. Jablonskytė-Rašce D., Maikštenienė S., Mankeviciene A. 2013. Evaluation of productivity and quality of common wheat (Triticum aestivum L.) and spelt (Triticum spelta L.) in relation to nutrition conditions. Zemdirbyste-Agriculture. Vol. 100(1). P. 45-56. Available from: http://dx.doi. org/10.13080/z-a.2013.100.007

13. Janušauskaite D. 2013. Spring triticale yield formation and nitrogen use efficiency as affected by nitrogen rate and its splitting. ZemdirbysteAgriculture. Vol. 100(4). P. 383-392. Available from: http://dx.doi.org/10.13080/z-a.2013.100.049

14. Jing R. L., Chang X. P. 2003. Genetic diversity in wheat (Triticum aestivum L.) germplasm resources with drought resistance. Acta Botanica BorealOccident Sinica. Vol. 23. P. 410-416.

15. Li J., Liu H., Duan L., Eneji E., Li Z. 2008. Spike differentiation in winter wheat (Triticum aestivum $\mathrm{L}$.) mulched with plastic films during over-wintering period. Journal of Sustainable Agriculture. Vol. 31(3). P. 133-144.

16. Petrenko V., Tanchik S., Podpryatov H. 2013. Processing on alcohol of wheat grain deprived of bakery properties due to agricultural systems. Annals of Agrarian Science. Vol. 11(3). P. 86-90.

17. Stahl M., Steiner A. 1998. Germination and vigour loss of non-sprouted and sprouted wheat seeds during storage - testing the viability constant. Seed Science Research. Vol. 8(2). P. 123-128.

18. Strelec I., Popovich R., Ivanišic I., Jurcovic V., Jurcovic Z., Hardi Z., Sabo M. 2010. Influence of temperature and relative humidity on grain moisture, germination and vigour of three wheat cultivars during one year storage. Poljoprivreda. Vol. 16(2). P. 20-24.

19. Tanchik S. P. 2009. No-till and Other Modern Agriculture Systems. Kiev: Univest Print. 160 p.

20. Tekrony D. M. 2006. Seeds: the delivery system for crop science. Crop Science. Vol. 3. P. 467-472.

21. Trufanov V., Permyakova M., Berezovskaya E. 2003. Aggregating ability of seed storage proteins from cereals differing in gluten quality. Applied Biochemistry and Microbiology. Vol. 39(4). P. 418-421. 
22. Villers P., Navarro S., De Bruin T. 2010. New application of hermetic storage for grain storage and transport. Julius-Kuhn-Archiv. Vol. 425. P. 446451. Available from: http://dx.doi.org/10.5073/ jka.2010.425.086

23. Adamenko T. 2012. Sostoyaniye posevov i perspektivy urozhaynosti ozimoy pshenicy v Ukraine. Zernovaya industriya. T. 20(2). C. 30-33 (in Russian).

24. Lobanov V. 2008. Opredeleniye posevnykh kachestv semyan pshenicy pri yeyë dolgosrochnom khranenii. Selektsiya i semenovodstvo. No. 5. C. 134-138 (in Russian).

25. Plonskiy V. I. 2003. Otsenka zernovykh zlakov na ustoychivost' $k$ neblagopriyatnym ekologicheskim faktoram. 125 p. (in Russian).
Vasyl Petrenko

\section{SKIRTINGOSE ŽEMDIRBYSTĖS SISTEMOSE AUGINTŲ ŽIEMINIŲ KVIEČIŲ (TRITICUM AESTIVUM L.) SĖKLOS LAIKYMO SĄLYGŲ POVEIKIS DAIGUMUI}

Santrauka

Straipsnyje nagrinëjama skirtinga žieminių kviečių sẻklos laikymo trukmè ir būdai. Darbo tikslas - laboratorijoje ištirti žieminių kviečių sèklos, žiemą laikytos trimis būdais ir šešiais periodais, daigumą bei nustatyti jos laikymo optimalų režimą. Žieminiai kviečiai buvo auginti Šiaurès Ukrainos išplautame juodžemyje (Luvic Chernozem) ir tręšti trimis būdais. Lauko ir laboratoriniai tyrimai atlikti Ukrainos nacionalinio gyvybės ir aplinkos mokslų universiteto Agronomijos tyrimų stotyje. Gauti rezultatai įvertinti taikant ANOVA metodiką.

Sèjos ir javapjūtés poveikis daugiau priklausé nuo oro sąlygų, sandèliavimo poveikis - nuo laikymo trukmès. Skirtingų žemdirbystès sistemų (tręšimo, augalų apsaugos) poveikis sèkloms išsilaikyti neviršijo $16 \%$. Nustatyta, kad optimalus žieminių kviečiu sèklos laikymo skirtingomis sąlygomis periodas - 6-18 mènesių. Norint laikyti ilgiau, reikia taikyti šalto sandèliavimo būdus.

Raktažodžiai: žemdirbystès sistema, daiginimas laboratorijoje, laikymo trukmè ir būdai, žieminių kviečių sèkla 